\title{
Copper metabolism in milch cows. IV. Proof of the method: the liver uptake in gravidity
}

\author{
W. Tj. Binnerts \\ Department of Animal Physiology, Agricultural University, Wageningen, The Nether- \\ lands
}

Received 3 March, 1966

\begin{abstract}
Summary
External liver measurement was performed in cows after intravenous or intramuscular injection of radio copper. The percentage liver uptake was distinctly lower in the last 6 months of pregnancy than before that time or in non-pregnant animals. This result confirms the hypothesis that the fetal liver derives its copper mainly from the maternal 'inorganic' blood copper rather than from the ceruloplasmin. The average uptake in groups consisting of about 10 cows was found 34 resp. 36 per cent at 3-6 months of pregnancy and at 6-9 months pregnancy, compared to 49 resp. 50 per cent of the dose in similar groups non-pregnant or less than 3 months pregnant. In eight cases in which individual animals could be followed during a longer period the uptake was 31 per cent on average at 3 months pregnancy and later, compared to 48 per cent of the dose with the animals non-pregnant or less than 3 months pregnant.
\end{abstract}

\section{Introduction}

It is known that mammals are born with appreciable liver copper stores. Somehow this copper is derived from the mothers, especially during the later phases of pregnancy. Some results of non radioactive measurement of biopsy samples, given by van der Grift (1955), do show even exhaustion of the maternal liver reserves prepartum and the succeeding replenishment in the first few months of lactation. The depletion effect could have resulted from two entirely different mechanisms. The fetal copper could have been transported as ceruloplasmin previously synthetised in the maternal liver, or it could have been derived from the loosely bound 'inorganic' copper in the bloodstream. The literature gives no conclusive proof for one of these mechanisms (see References, under Reviews).

If the proposed method of external determination of radio copper in the liver is practicable, it should give distinct differentiation. In the first case the half-life of the maternal radio copper would be lowered and in the second case the percentage liver uptake would be depressed (both cases compared to non pregnant similar individuals under identical feeding conditions). We confine ourselves here to the uptake studies. Some complication can be expected to occur. The highly producing animal with its increased feed intake, absorbs a surplus of copper, especially indoors when concentrates are being offered. Repeat analysis has given an average copper content of our protein-rich concentrates ('A-brokken') of $30 \mathrm{mg} / \mathrm{kg}$ dry matter. This is about three 
Table 1 Depression of liver uptake by copper ingestion

\begin{tabular}{llcc} 
Name of the cow & Environment & Percentage uptake when dosed & Normal average \\
Lionne 12 & pasture & $28 ; 20$ & $<50$ \\
Nelly 7 & stalls & 44 & 50 \\
Witschoft 6 & pasture/stalls & 19 & 34 \\
Witschoft 7 & pasture & 22 & 36 \\
\hline
\end{tabular}

1 From Table 3

Table 2 Protocol of the experimental animals

\begin{tabular}{|c|c|c|c|c|c|}
\hline $\begin{array}{l}\text { Name of } \\
\text { the cow }\end{array}$ & $\begin{array}{c}\text { Date of } \\
\text { experiment }\end{array}$ & $\begin{array}{c}\text { Pasture/ } \\
\text { indoors }\end{array}$ & $\begin{array}{l}\text { Next } \\
\text { calving }\end{array}$ & $\begin{array}{c}\text { Milk } \\
\text { production } \\
(\mathrm{kg} / \text { day })\end{array}$ & $\begin{array}{c}\text { Concentrate } \\
\quad(k g / \text { day })\end{array}$ \\
\hline Annie 8 & $12-3-63$ & I & end of June & 6.5 & 2.5 \\
\hline Betsie 2 & $30-8-63$ & $\mathbf{P}$ & 8- 1-64 & 11 & - \\
\hline Zwarts. 9 & $30-8-63$ & $\mathbf{P}$ & $22-12-63$ & 8 & - \\
\hline Betsie 2 & $23-10-63$ & $\mathbf{P}$ & 8- $1-64$ & 5 & - \\
\hline Zwarts. 9 & $23-10-63$ & $\mathbf{P}$ & $22-12-63$ & 5 & - \\
\hline Eke 44 & $10-12-63$ & I & non pregn. & 25 & 4 à 5 \\
\hline Lamkje 6 & $10-12-63$ & I & non pregn. & 24 & 4 à 5 \\
\hline Zwarts. 11 & $10-12-63$ & I & 9. $4-64$ & -1 (first & - \\
\hline Lionne 16 & $10-12-63$ & I & 7- $4-64$ & - J calf) & - \\
\hline Zwarts. 9 & $28-1-64$ & I & non pregn. & 16 & 3 \\
\hline Witsch. 7 & $28-1-64$ & i & non pregn. & 16 & 3 \\
\hline Anna 5 & $28-1-64$ & I & $13-4-64$ & - & - \\
\hline Lionne 12 & $28-1-64$ & I & 9- $3-64$ & - & - \\
\hline Lionne 12 & 5- $5-64$ & 1 & l non pregn. & 17 & 3 \\
\hline Betsie 2 & 5- $5-64$ & $\mathbf{P}$ & $\int d r y 11-12-64$ & 27 & - \\
\hline Zwarts. 11 & $10-11-64$ & I & $20-3-65$ & 10 & 2 \\
\hline Lamkje 9 & $10-11-64$ & I & 9- 2-65 & 2 & 2 \\
\hline Zwarts. 9 & $10-11-64$ & 1 & $10-1-65$ & 4 & 2 \\
\hline Zwarts. 12 & $10-11-64$ & I & $22-4-65$ & 8.5 & 2 \\
\hline Zwarts. 8 & & $\mathbf{I} / \mathbf{P}$ & $17-12-65$ & 6.5 & $3 /-$ \\
\hline Witsch. 7 & $27-4-65$ & $\mathbf{I} / \mathbf{P}$ & non pregn. & 14.5 & $3 /-$ \\
\hline Lionne 17 & 4- $5-65$ & I & non pregn. & 22 & $5 /-$ \\
\hline Maartje 310 & & I & 4- $4-66$ & $22 / 11$ & $5 /-$ \\
\hline Zwarts. 11 & & $\mathbf{P} / \mathbf{I}$ & $1-4-66$ & 11 & 5 \\
\hline Zwarts. 12 & $17-8-65$ & $P / I$ & $1-4-66$ & 13.5 & 5 \\
\hline Witsch. 10 & 7-9-65 & $\mathbf{P} / \mathbf{I}$ & $13-10-65$ & - & 3 \\
\hline Anna 10 & & $\mathbf{P} / \mathbf{I}$ & $21-10-65$ & - & 3 \\
\hline Nellie 7 & $12-3-63$ & I & 12. $9-63$ & 10 & 2.5 \\
\hline Lionne 12 & $30-8-63$ & $\mathbf{P}$ & 9. $3-64$ & 10 & 一 \\
\hline Witsch. 7 & $30-8-63$ & $\mathbf{P}$ & $10-11-63$ & 7 & - \\
\hline Witsch. 6 & $23-10-63$ & $\mathbf{P}$ & 3- $2-64$ & 5 & 一 \\
\hline Lionne 12 & $23-10-63$ & $\mathbf{P}$ & 9- $3-64$ & 7 & - \\
\hline Aaltje 4 & $5-11-63$ & $\mathbf{P}$ & $20-3-64$ & 10 & - \\
\hline Aaltje 5 & $5-11-63$ & $\mathbf{P}$ & $11-3-64$ & 8 & - \\
\hline Aaltje 21 & $5-11-63$ & $\mathbf{P}$ & $28-4-64$ & 8 & - \\
\hline Aaltje 22 & $5-11-63$ & $\mathbf{P}$ & $11-3-64$ & 9 & - \\
\hline
\end{tabular}


times as high a content as in grass or hay. But also grass and hay, though about equal in copper content d.m., could induce different levels of copper absorption.

\section{Preliminary experiments}

In order to obtain a preliminary insight in the action of surplus copper intake, some cows were dosed with copper sulphate (two times daily $1 \mathrm{~g}$ administered by balling gun). From the results in Table 1 it follows that the administration tends to reduce the liver uptake values.

Other experiments, which will be reported in detail later, revealed that cows on pasture, although generally ingesting less total copper, accumulate somewhat smaller amounts of radio copper in their livers than indoors. It should be remembered that the copper was administered intramuscularly or intravenously, so that the observation points to disturbed partition of the available copper over the body compartments.

\section{Radioactive liver copper and pregnancy}

The material already published (Binnerts, 1964, 1965), together with some additional results obtained since then, has been arranged according to the data of subsequent calving, the quantity of milk production, wether or not indoors and the amount of concentrate fed. The protocol of the experiments is given in Table 2.

In this table separately included are animals under copper administration and four animals from a different farm. It will be seen that their influence on the averages is quite small (Table 3).

Table 3 makes it clear that the proposed method of external liver measurement serves well to distinguish between the radio copper uptakes of animals in the last 6 months of pregnancy and those before this period or non gravid.

It may be interesting to note that in the work of van der Grift (1955) the liver biopsies started about 4 months before calving. From his averages it seems quite probable, however, that the depletion of the liver copper stores had already been

Table 3 Depression of liver uptake by pregnancy

\begin{tabular}{lcc}
$\begin{array}{l}\text { Months before } \\
\text { calving }\end{array}$ & $\begin{array}{c}\text { Number of } \\
\text { animals }\end{array}$ & $\begin{array}{c}\text { Average uptake } \\
\text { of radio copper } 1\end{array}$ \\
Non pregnant & $10(10)^{3}$ & $49 \pm 2.5^{2}$ \\
$9-6$ & $6(10)^{4}$ & $50 \pm 5.5(47 \pm 4.9)$ \\
$6-3$ & $7(13)^{3}$ & $34 \pm 3.7(31 \pm 2.5)$ \\
Less than 3 & $9(11)^{*}$ & $36 \pm 4.8(35 \pm 4.5)$ \\
\hline
\end{tabular}

The numbers in parentheses refer to all experiments, those from a different farm and those with extra copper included.

1 In liver, from intravenous or intramuscular dosage, in $\%$ dose

2 Standard error of the mean

3 Nine of the ten cows indoors with possible concentrate feeds

\& Pasture/indoors $50 \%$

5 Two out of six animals on pasture

- Three out of nine on pasture 
Table 4 Identical cows in different phases

\begin{tabular}{l} 
Non pregnant \\
$\begin{array}{l}\text { Pregnant up to } 3 \text { months } \\
\left.\begin{array}{l}\text { Pregnant } 3 \text { and more } \\
\text { months }\end{array}\right\}\end{array}$ \\
\hline
\end{tabular}

Of these 3 times on pasture

Also 3 times on pasture

going on before that time. It might be possible to determine more exactly the start of the fetal liver competition, but from the limited material presented here no more can be concluded than that the influence became manifest somewhere between the 5th and 7 th month prepartum.

The quantity of the depression seems to be a constant $15 \%$ of the dose on the average during the entire 6 months period; this is about $30 \%$ relative to the normal maternal liver supply. In Table 3 the number of cows on pasture is given explicitly. The observed differences cannot be caused by hay versus grass feeding or by additional copper in concentrates. The preliminary studies have shown that if any effect is present, it will have worked in the opposite direction. To check between-animal effects, the comparison given in Table 4 has been carried out. It reveals about the same differences with identical animals as found before.

No information was found in the literature regarding the source of the fetal liver copper. It is clear from the results presented here that the fetal liver works quite independantly from the mother with respect to its copper metabolism and that it accumulates the 'inorganic' copper from the blood stream. In order to make this possible this copper should be able to cross the placental barrier.

\section{Some calculations}

a) Animals in our experiments. They received $5 \mathrm{~kg}$ d.m. of hay during the last months before calving, with an average of 10 p.p.m. $\mathrm{Cu}$ in dry matter. This resulted in $50 \mathrm{mg}$ copper intake daily and with a reasonable $10 \%$ availability, a gross $5 \mathrm{mg}$ is calculated to be absorbed daily.

b) Animals under average feeding conditions in The Netherlands. The average hay consumption is higher than in our experiments: according to the C.V.B. tables it amounts to at least $9 \mathrm{~kg} \mathrm{d.m}$. daily for dry animals. On the other hand the average copper content of hay is a low 7.7 p.p.m. dry matter (Rameau, 1965) so that the resulting intake will be at least $70 \mathrm{mg} /$ day. In experiments with 'practical' rations the (true) availability of copper is assumed to be only $6-8 \%{ }^{1}$ so that in these circumstances also a gross $5 \mathrm{mg}$ of copper may be absorbed daily.

1 The author is indebted to Ir. J. Hartmans, Institute for Biological and Chemical Research on Field Crops and Herbage (I.B.S.), Wageningen, for this figure and for the first extension of the argument in the b)-section. 
The liver copper losses due to pregnancy will be $15 \%$ or - based on this calculated $5 \mathrm{mg}$ of available copper $-0.75 \mathrm{mg}$ daily and this will amount to a gross $10 \mathrm{mg}$ per $\mathrm{kg}$ liver d.m. per month. This result compares excellently with van der Grift's average of four animals, which declines from 107 to $69 \mathrm{mg} / \mathrm{kg} \mathrm{d.m}$. in 4 months (values interpolated from his graph on p. 43). The fifth animal of his experiments is left out of his calculations because of the low liver copper value of only 7 p.p.m. 4 months prepartum. It would certainly be of interest to perform measurements with radio copper also on similar depleted cows. In a preliminary experiment with two pregnant cows having blood copper contents of only 12 and $24 \mu \mathrm{g} / 100 \mathrm{ml}$ (probably indicating liver copper about $10 \mathrm{mg} / \mathrm{kg}$ d.m. or less; van der Grift, 1955) liver copper uptakes were found of $25 \%$ and lower.

A scheme of the pathway of copper metabolism, in so far it is important to our experiments, is given in Fig. 1. It may be noted that also in the case of low copper reserves in the mother the growing fetus is able to accumulate considerable copper. Van der Grift (1955) gives examples in which 316 and 239 p.p.m. d.m. in the livers of newborn animals was found, whereas the mothers $24 \mathrm{~h}$ after calving had only 18 and 3.25 p.p.m. d.m., respectively. The liver value in these calves was not much less than that (447 p.p.m.) of a calf born to a mother with a reserve of more than 200 p.p.m. d.m. Because in his experiments values below 25 p.p.m. d.m. in mature

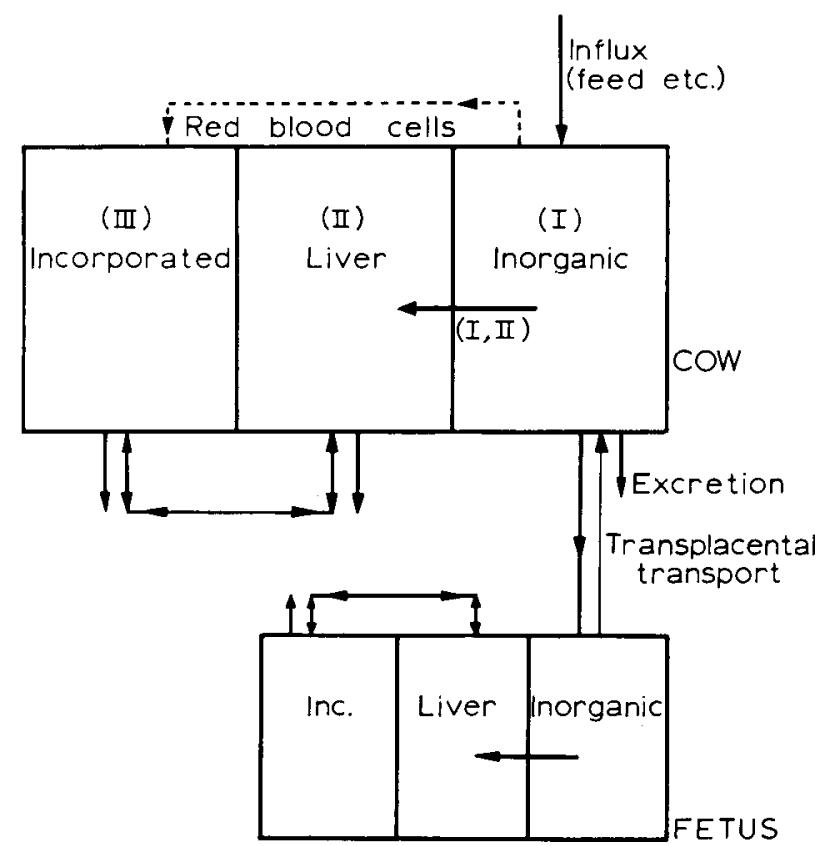

Fig. 1 Scheme of the copper compartments and copper pathways, in so far they are related to the results of this study. In copper deficiency the important pathway of the liver uptake (I, II) is reduced; as a consequence depletion of (II) occurs and finally (III) - in the body outside the liver, e.g. as ceruloplasmin in the blood plasma - will be lowered. Except for extreme deficiency the transplacental transport will only be slightly reduced. But then the uptake (I, II) seems to be limited further by less avidity of the maternal liver. 
cows correlate with blood copper contents (mainly ceruloplasmin), in such cases subnormal function with respect to the copper metabolism is indicated. The deficient cows in the examples given above will then also synthetise and excrete subnormal amounts of protein-bound copper to the bloodplasma. Thus they will not further deplete their liver copper reserves beyond the level which is needed for the metabolism of the liver cells proper. This reasoning can be reconciled well with the scheme reproduced in Fig. 1.

A second extension can be made to the above given calculations. It seems quite reasonable that not only the liver uptake, but also the other maternal uses of copper will be reduced by the needs of the fetus. The total reduction could then be two times the calculated amount, that is $1.5 \mathrm{mg}$ daily. (We remember here, that only $50 \%$ of the radioactive dose normally goes to the liver.) To maintain the agreement with the results of van der Grift, it should be realised that also in the young animal appreciable quantities of copper are located outside the liver; in the new-born animal this amounts to about $50 \%$ of the total.

The calculated $1.5 \mathrm{mg} /$ day is about the same as the quantity secreted with the milk. Results from Koppejan and Mulder (1953), with an assumed initial production of $20 \mathrm{~kg}$ of milk daily, point to the fact that on the average $3 \mathrm{mg}$ of copper per day is secreted in the milk during the first 2 weeks of lactation, declining to $1.5 \mathrm{mg}$ during the following month and to less than $1 \mathrm{mg}$ thereafter. It is quite understandable therefore that the decrease of the maternal copper stores continues for a short period after calving (van der Grift, 1955, fig. 7). Then these stores rise sharply because of the smaller drain and the increased supply with copper in concentrates, initiated near the onset of the milk production. In order to obtain the needed quantities of $1.5-3.0 \mathrm{mg}$ daily the cows will have to ingest an additional $15-30 \mathrm{mg}$ of copper, or they will deplete their copper stores. The total quantity of feed copper in the later stage of pregnancy and in the first few months after calving would therefore be $15-30 \mathrm{mg}$ added to the provisionally adopted $70 \mathrm{mg}$ (see before), that is in toto $85-100 \mathrm{mg}$ daily.

Finally, calculation of the liver copper of the new-born animal reveals that of the copper supplied by the mother not much is lost. With 400 p.p.m. d.m. of $\mathrm{Cu}$, the calf liver, owing to its small weight, does not contain more than approximately $50 \mathrm{mg}$ of the element. We have calculated a $60 \mathrm{mg}$ supply to the calf's liver during the 6 months period. As has been mentioned before, apart from this, the new-born animal contains another $50 \mathrm{mg}$ in the other body compartments.

\section{Conclusions}

The method of external liver measurement after intravenous or intramuscular administration of radio copper served well to distinguish between non-pregnant and pregnant cows from a time \pm 6 months prior to calving. On the average the liver copper uptake was found to be reduced to $35 \%$ instead of the usual $50 \%$. This observation is interpreted as resulting from competition for the circulating inorganic blood copper by the fetal liver. Based on these observations and additional reasonable assumptions, some calculations were performed on the depletion of the mother animal and the accumulation by the fetal liver. Also losses by way of the milk were calculated and finally the amount of copper needed by the pregnant and lactating cow to maintain 
copper equilibrium. The minimal requirement seems to be somewhere between 85 and $100 \mathrm{mg}$ daily. But this is an average and due provision should be made for the less fortunate animals, with smaller efficiency of resorption and/or liver uptake.

\section{Acknowledgements}

The author wishes to express his gratitude to drs. M. M. Wintrobe and G. E. Cart wright, University of Utah College of Medicine, Salt Lake City, Utah, U.S.A. for kind provision with partly not yet published literature and for helpfull discussion. The Netherlands Organization for the Advancement of Pure Research (Z.W.O.) has given financial support by a travel grant from New York City.

\section{References}

Binnerts, W. Tj., 1964. Copper metabolism in milch cows. I. A proposed method of liver measurement after injection of radio copper. Neth. J. Agric. Sci., 12: 310-317.

Binnerts, W. Tj., 1965. Use of ${ }^{64} \mathrm{Cu}$ in studies on the copper metabolism in milk cows. I.A.E.A.F.A.O. Conference on Radioisotopes in Animal Nutrition and Physiology, Prague.

Grift, J. van der, 1955. Het kopergehalte van lever en bloedserum bij het Fries-Hollandse rund. Thesis, Univ. Utrecht.

Koppejan, C. A. and Mulder, H., 1953. The copper content of milk. Proc. 13th Int. Dairy Congr., 3 : 1400-1401.

Rameau, J. Th. L. B., 1965. Het mineralengehalte van Nederlands hooi. Veeteelt Zuivelber., $8: 452$ 462 .

Reviews

Adelstein, S. J. and Vallee, B. L., 1962. Copper. In: Mineral Metabolism, C. L. Comar and F. Bronner (Editors). Acad. Press, London, 2B, pp. 371-401.

Bersin, Th., 1963. Biochemie der Mineral- und Spurenelementen. Akad. Verlag, Frankfurt, pp. 386401.

McElroy, W. D. and Glass, B. (Editors), 1950. Copper Metabolism - A Symposium. Hopkins, Baltimore.

Cartwright, G. E. and Wintrobe, M. M., 1964. Copper metabolism in normal subjects. Am. J. Clin. Nutr., $14:$ 224-232.

Cartwright, G. E. and Wintrobe, M. M., 1964. The question of copper deficiency in man. Am. J. Clin. Nutr., $15: 94-110$.

Underwood, E. J., 1953. Trace elements. 11. Copper. In: Biochemistry and Physiology of Nutrition. Acad. Press, New York, 2: 430-448. 